IZA DP No. 6542

Moroccans', Ecuadorians' and Romanians' Assimilation in Spain

Núria Rodríguez-Planas

Raquel Vegas

May 2012 


\title{
Moroccans', Ecuadorians' and Romanians' Assimilation in Spain
}

\author{
Núria Rodríguez-Planas \\ $I Z A, I A E-C S I C$ and UPF \\ Raquel Vegas \\ FEDEA
}

Discussion Paper No. 6542

May 2012

IZA

P.O. Box 7240

53072 Bonn

Germany

Phone: +49-228-3894-0

Fax: +49-228-3894-180

E-mail: iza@iza.org

\begin{abstract}
Any opinions expressed here are those of the author(s) and not those of IZA. Research published in this series may include views on policy, but the institute itself takes no institutional policy positions.

The Institute for the Study of Labor (IZA) in Bonn is a local and virtual international research center and a place of communication between science, politics and business. IZA is an independent nonprofit organization supported by Deutsche Post Foundation. The center is associated with the University of Bonn and offers a stimulating research environment through its international network, workshops and conferences, data service, project support, research visits and doctoral program. IZA engages in (i) original and internationally competitive research in all fields of labor economics, (ii) development of policy concepts, and (iii) dissemination of research results and concepts to the interested public.
\end{abstract}

IZA Discussion Papers often represent preliminary work and are circulated to encourage discussion. Citation of such a paper should account for its provisional character. A revised version may be available directly from the author. 


\section{ABSTRACT}

\section{Moroccans', Ecuadorians' and Romanians' Assimilation in Spain ${ }^{*}$}

Using the 2007 Encuesta Nacional de Immigración (ENI), we find that male migrants follow a similar labor and legal assimilation pattern in Spain regardless of their nationality (with Romanians faring worse in terms of legal status but better in terms of employment status at arrival). Among women, Moroccans and Ecuadorians follow a similar pattern that contrasts with the one observed among Romanian women. While the former mainly arrive to Spain to work with legal status and with time in Spain (some of them) move out of employment, the latter are considerably (and persistently) more attached to the labor force, although they tend to lack legal status at arrival, and only gain such status overtime. Controlling for observable characteristics and using Heckman-corrected estimates, our wage analysis finds that with the exception of Moroccan and Romanian males for which no wage differences are observed, Moroccans outperform the other two nationalities in terms of higher wages at arrival. Moreover, this wage differential does not decrease over time.

JEL Classification: J15, J24, J61, J62

Keywords: legal and employment assimilation, Southern and Eastern Mediterranean men and women

Corresponding author:

Núria Rodríguez-Planas

Visiting Research Fellow

IZA

P.O. Box 7240

53072 Bonn

Germany

E-mail: rodriguez-planas@iza.org

\footnotetext{
* Núria Rodríguez-Planas acknowledges financial support from the Spanish ministry of Education and Science (grant SEJ2006-712), the Generalitat de Catalunya (grant SGR2005-712), and the Barcelona GSE (through CREMed). Raquel Vegas acknowledges financial support from the Barcelona GSE (through CREMed).
} 


\section{Introduction}

Spain has recently experienced an unprecedented immigration boom in a short period of time-with immigrants increasing from 1 percent of the population in 1990 to 12 percent in 2009, and an average annual flow of immigrants of 500,000 per year. This is partly explained because Spain has been an immigrant-friendly country with a lax implementation of immigration laws and several generous amnesties granting legal residence to illegal immigrants (Dolado and Vázquez, 2007; Izquierdo et al., 2009, among others). ${ }^{1}$ Within this context, this paper presents a case study analysis of how three different nationalities-Moroccans, Ecuadorians, and Romanians_-assimilate in terms of labor market and legal status in the country. These three nationalities are important in Spain as they represent all together between 23 and 32 percent of immigrants to Spain in the year 2007 (the lower bound is from the 2000 Census, the upper bound is from the 2007 Spanish Municipal Registry of Inhabitants). We argue that understanding the legal and labor market assimilation of low-skilled (often irregular) migrants is of great policy relevance not only for economic, but also for social reasons.

For this purpose, we use the 2007 Encuesta Nacional de Immigración (ENI). The advantage of the ENI is that it contains rich and detailed information on the immigration process and the labor market involvement before and after arrival in the host country, enabling us to reconstruct the employment history of immigrants from prior to departure from Morocco to arrival in Spain and (finally) to the survey date. The analysis uses a bivariate probit model that jointly estimates legal and employment status, and OLS, and Heckman-corrected regressions when analyzing earnings.

\footnotetext{
${ }^{1}$ An assumption here is that if people migrate to Spain to work, it is because there are jobs available. In the case of Spain at the time under analysis, this assumption seems to hold.
} 
Evidence of employment differences by nationality implies that failure to account for these differences when estimating the earnings equation may bias the earnings results.

The three groups of migrants under analysis represent by far the three largest groups of immigrants in Spain in 2007. Ecuadorians represent 9.2 percent of all migrants in Spain in 2007; Romanians follow in importance with 11.2 percent of the share; and Moroccans are the largest group with 11.6 percent of the share. Moreover, there are at least three important differences across these three groups that make their analysis policy relevant. First, they come from three different continents with very distinct histories and immigration patterns: Latin America, (Eastern) Europe, and Africa. Second, they differ in language skills as only Ecuadorians have Spanish as their mother tongue. Third, they differ in their tradition of migrating towards Europe in general, and Spain, in particular. While Moroccans have a longstanding tradition of migrating toward Europe (and Spain) dating from the 1960s (1980s), Ecuadorians large inflows date from the turn of the century and coincide with a direct consequence of the social, economic, fiscal, and monetary crisis in the country of origin. Finally, Romanians are the most recent arrivals after the 1990s, soon after the fall of the Berlin wall.

A priori it is not obvious which of these three nationalities ought to outperform in terms of legal or employment assimilation. On the one hand, Moroccans and Ecuadorians are less educated and thus may have more difficulties finding good jobs than Romanians. Moreover, Moroccan women may be less prone to work (as they may specialize in home production) compared to Ecuadorian or Romanian women. Finally lack of language skills at arrival for Moroccans and Romanians may slow down the labor market assimilation process. On the other, given that Moroccans have a long tradition of migrating to Spain, they are more likely to have a family member or friend 
nearby making it easier to have access to (better) jobs or information on how to apply to (better) jobs.

It is important to note that by having information on employment status before migrating and at arrival in Spain; we are able to potentially address an important individual self-selection problem, as we will compare migrants from different nationalities holding constant their employment history before and at arrival in the host country. Finally, because the literature review shows that the Southern Mediterranean region displays unique gender characteristics such as patriarchy, high fertility, malebreadwinner model, and low rates of education and waged work outside the home for women (Omran and Roudi, 1993; Yasmeen, 2004; McQuilan, 2004; Foroutan, 2008a,b,c; Foroutan, 2009), the analysis is disaggregated on the basis of gender.

Our contribution to the literature is threefold. First, we use a sample of legal and illegal immigrants (as opposed to only legal migrants, as is standard in the literature that uses visa information). Second, we are able to jointly model the employment and legal status decision as they are both heavily intertwined. Third, while most studies have limited information on observable characteristics, such as education, experience and language, our dataset also contains information on employment status prior to departure, as well as information on networks at arrival and at survey date in the host country. We are thus able to explore their effect on legal and employment outcomes.

We find that male migrants follow a similar labor and legal assimilation pattern in Spain regardless of their nationality (with Romanians faring worse in terms of legal status but better in terms of employment status at arrival). Among women, Moroccans and Ecuadorians follow a similar pattern that contrasts with the one observed among Romanian women. While the former mainly arrive to Spain to work with legal status, and, with time in Spain, (some of them) move out of employment; the latter are considerably (and persistently) more attached to the labor force, although they tend to lack legal status at arrival, and only gain such status 
overtime. Controlling for observable characteristics and using Heckman-corrected estimates, our wage analysis finds that with the exception of Moroccan and Romanian males for which no wage differences are observed, Moroccans outperform the other two nationalities in terms of higher wages at arrival. Moreover, this wage differential does not decrease over time. This results seem to indicate the importance of have a tradition of migrating to the country of origin.

The paper is organized as follows. The next section presents background information. Section III describes the data and the descriptive statistics. Section IV explains the methodological approach, and analyzes the results. Section V concludes with a discussion on policy implications.

\section{Background Information}

\section{Moroccan Immigration}

Over the second half of the 20th century, Morocco has evolved into one of the world's leading emigration countries. Since the early 1960s, this country has a longstanding tradition of sending migrants towards France, Belgium and the Netherlands. However, legislation changes from the 1980s limiting migration in the traditional receiving countries in Europe led to a shift of Moroccan low-skilled (often irregular) migration towards Spain and Italy that has lasted until today. As of 2007, according to the Spanish Labor department, as many as 648,735 Moroccans had a resident permit in Spain (representing over 16.3 percent of legal immigrants in this country). In terms of the Moroccans living in Spain (regardless of their legal status), the Encuesta de la Población estimates that in 2007 there were 706,666 Moroccans in the Spanish territory, representing 11.6 percent of all immigrants. This group of migrants has been observed to be clustered at the end of the occupational spectrum and in low-skilled sectors, such as agriculture (30 percent), construction (27 percent), and services (36 
percent), highlighting their potential vulnerability and increasing their policy relevance both for economic and social reasons.

\section{Ecuadorians Migration}

In contrast with Moroccans who have a long tradition migrating to Europe and Spain, Ecuadorians have only recently changed their country of destination from the US to Spain. According to Bertoli et al., 2011, the scale of Ecuadorians migration flows to Spain over the 1999-2005 is almost three times larger than that to the US (the traditional country of destination). The timing coincides with a period of hyperinflation and large GDP losses in the late 1990s that led to the dollarization of the domestic currency and to an extreme vulnerability of the country to external shocks. Right after the turn of the century, many Ecuadorians fled the country, choosing Spain as their preferred destination. The size of the Ecuadorian community in Spain soared within five years, going from 76,000 to 457,000 individuals by 2006 .

\section{Romanians Migration}

The sharp inflow observed among Ecuadorians is relatively small compared to the massive arrival of Romanians in Spain after the turn of the century. While there were no more than 3,000 Romanians in Spain in 1999, a decade later, close to 800,000 Romanians were living in Spain. Romanians are particularly interesting to study because beginning January $1^{\text {st }}, 2007$ their country became part of the European Union, implying that they were free to enter and reside in Spain. Moreover, the Real Decreto $340 / 2007$ allowed them to work or be self-employed with the same rights as nationals as long as they could prove a minimum residence of two years in Spain. Thus, although most of our data covers the year 2007 (and retrospectively), it is likely that many Romanian migrants may have anticipated this legal change that facilitated their legal and employment assimilation process. 


\section{Spanish Assimilation Process}

Several authors have recently analyzed immigrants' assimilation in Spain by looking at wages or immigrants' labor market success, and distinguishing by continent of origin. The bottom line is that, although labor-market assimilation of immigrants takes place, convergence is far from occurring, with immigrants segregating into lower paid occupations and more vulnerable jobs. The situation for Africans is even worse as their assimilation is slow and they remain in a vulnerable economic situation. Using 2001 decennial Population Census data, Amuedo-Dorantes and de la Rica, 2007, study the occupational assimilation process of the immigrants who arrived in Spain between 1996 and 2000, prior to the immigration boom. While these authors find evidence that nonEU15 and Latin American immigrants assimilate employment- and occupation-wise, there is limited evidence of labor market assimilation among immigrants from Africa. Using cross-sectional data from 1999 to 2009, Alcobendas and Rodriguez-Planas, 2009, analyze the occupational assimilation process after the Spanish immigration boom, finding less optimistic results for the new waves of immigrants. On the one hand, these authors find little sign of assimilation among non EU-15 female immigrants (especially those from Africa) and regardless of their educational level. On the other, they find that, among non-EU-15 male immigrants, the degree of assimilation is higher the lower their education level, with the exception of African males who (again) have a harder time to assimilate. Using the same data but from 1996 to 2005, Fernandez and Ortega, 2008, also find that among immigrants, Africans are those faring worse in terms of returns to education, labor market assimilation, and higher sensitivity to the business cycle. Similarly, Sanromá et al., 2009, find that immigrants coming from developing or culturally distant countries have lower average wages and show a relatively more compressed wage distribution than natives. The authors suggest that occupational 
segregation is part of the story behind these wage differences. Finally, using recently available panel data from Social Security records, Izquierdo et al., 2009, find that, despite a sizeable and significant reduction in the gap between legal immigrant men working in wage and salary jobs in the formal sector and their native counterparts within 5 years of arrival in Spain, full equality of wages does not take place as a 15 percentage points wage differential remains. They also find that, on average, Africans fare the worse.

To the best of our knowledge, no one has yet compared the legal and employment assimilation across the three largest nationalities of migrants in Spain. Some authors have focused on studying different aspects of each of these three different groups of migrants one at a time. For instance, Rodríguez-Planas and Vegas, 2011, analyze whether Moroccan immigrants who arrive on the basis of family relationships rather than labor market opportunities in Spain have better legal and employment status (including earnings) immediately after migration, and whether this represents a longterm advantage or disadvantage in the labor market. These authors find that, even when focusing on a very homogenous group of migrants (Moroccans) who tend to be low-skilled, and after controlling for migrants' self-selection with employment history prior to and at arrival, family-based immigrants are less likely to work than their labor-based counterparts both at arrival and ten years later. Their Heckman-corrected estimates highlight that there are no monthly earnings differences by reason of arrival, and that failure to correct for labor force participation strongly biases these results.

Ecuadorians' migration process to Spain has been studied by Bertoli et al., 2011. These authors analyze why most Ecuadorian migrants opted for Spain rather than the US, which on top of being the traditional destination also offered the highest wages. They argue that differences in the immigration policies adopted by the US and Spain explain this puzzle. More specifically, the puzzle is explained by the combination of the 
following two factors: first, the options to migrate legally to either destination were slim, and, second, the cost of illegally migrating to Spain was lower than to the US. Finally, Dueñas Fernández and Iglesias Fernández, 2011, analyze the assimilation process of Romanians and Bulgarians in Spain from 2000 to 2009 . They find that migrants from these two countries perform better in the labor market than other migrants, and that this differential increases with years since arrival.

\section{Data and Descriptive Statistics}

We use a retrospective micro database that has been derived from the National Immigrant Survey (ENI-2007). The National Immigrant survey (ENI-2007) was administered to approximately 15,500 non-native current residents of Spain between the months of November 2006 and February 2007. All persons 16 years and older who were born abroad and who had been in Spain for at least one year were eligible to be interviewed. For those who had been in Spain for less than a year, their intent to remain in the country for at least a year also qualified them for participation in the survey. A resident is a person who is present in the country regardless of her legal status. The Spanish Statistical Office designed the strategy for locating informants. This task was based on the existence of the Municipal Register or Padrón Municipal. A response rate with respect to the effective sample eligible respondents of 87.4 percent was obtained (15,465 interviews). The results of this survey are statistically representative of Spain, for the main migrant origins and for the major regions of the country. All results are weighted according to the sample frame set up by the Spanish Statistical Office.

The survey includes information on socio-demographic characteristics of immigrants (including language skills, education, fertility, and marital status, among others), household structure, current place of residence, conditions upon departure from 
their country of origin and arrival in Spain, personal migration histories, and country of origin.

Restricting our attention to those individuals who were born in Morocco, Ecuador or Romania who were between 19 and 55 years old and who provided information about their year of arrival leaves us with a dataset of 3,636 observations, of which 53.47 percent are males (1,944 observations). Moroccans represent 37.07 percent of the sample, Ecuadorians represent 30.94 percent and Romanians represent 31.99 percent. Table 1 shows that while more than half of Ecuadorians ( 55 percent) and Romanians (53 percent) living in Spain in 2007 are women, the opposite is true for Moroccans (35 percent).

Table 1 also presents the summary statistics of migrants' observable characteristics. As we explained earlier, Moroccans are those who arrived sooner in the host country (the median migrant arrived in the late 1990s), Ecuadorians follow (the median migrant arrived at the turn of the century), and Romanians are those who have arrived more recently to Spain (with 2003 as the median year of arrival). At survey date Moroccans and Ecuadorians have, on average, similar age (men's average is 36 years old, and women's average is 35 years old), and are between 2 and 3 years older than Romanians. The least educated migrants are Moroccans with more than half of them holding only primary education. In contrast the most educated ones are Romanians with more than half of them holding a high school degree or above. However, there are small differences across nationalities in terms of college educated migrants. Between 7 percent of males and 12 percent of females hold a university degree (this percentage being slightly smaller for Moroccan women). Moroccans are the most likely to be married or cohabitating, while Ecuadorians are the least likely. Although Ecuadorians and Romanians are more likely to have worked in their home country, this may just be a 
consequence of the fact that they migrated at a later age (as they are about 5 years older at migration than Moroccans). Interestingly, about 10 percent of Moroccans and Ecuadorians had a job in Spain prior to migrating compared to 14 percent of Romanians, but within 30 days of arrival to Spain, Ecuadorian women are by far those more likely to be working (61 percent of them). They are followed by their male counterparts, Romanians, and Moroccans_-with about 45 percent of them working within a month after arrival. Women tend to participate more in co-ethnic associations than men, with the gender difference being the largest among Romanians and the smallest among Moroccans. In contrast, there are small differences across gender or nationalities in the percentage of migrants participating in Spanish associations (around 10 percent of migrants in our sample do so). A striking difference is that while more than 80 percent of Ecuadorians or Romanians knew someone in Spain prior to arrival, less than two thirds of Moroccans have some prior contact in the host country. Finally, it is worth highlighting that Moroccans frequently return to their home country (on average between 12 and 15 times), in sharp contrast with Ecuadorians or Romanians who have gone less than 3 times. While this may be partly explained by the less amount of time Romanians have resided in Spain, in the case of Ecuadorians, the difference is likely due to the geographic distance of Ecuador and the relatively high airfare costs.

Table 2 displays summary statistics of selected outcome variables by country of origin and sex. The first important difference is that Romanians are considerably less likely to be legally residing in Spain than the other two nationalities. While close to 60 percent of Romanians are legally living in Spain, as much as 90 percent of Moroccans and Ecuadorians do. A priori this comes as a surprise because since 2007 Romanians are allowed to reside in Spain just as any other EU member. It is also concerning 
because in order to be able to work in Spain, Romanians have to show proof of residence for at least two years. Thus, the fact that so many of them self-report as illegally residing in Spain is evidence of either lack of knowledge of their preferential status as migrants or that they are not officially in the country.

The second important difference from Table 2 is that Moroccans are considerably less likely to work at survey date than the other two nationalities. Indeed while 61 percent of Moroccan males and 53 percent of Moroccan females report working at survey date, as much as 75 percent of Romanians and 78 percent of Ecuadorians do so. This is particularly striking given that Moroccans are between one and five years more likely to have been in the country than Ecuadorians and Romanians.

Among those who work, Moroccans earn more than Ecuadorians who earn more than Romanians. And women earn less than men, regardless of the nationality. Clearly these observed differences across country of origin are just descriptive, and given the compositional differences that we have observed in Table 1, multivariate regression analysis is needed to try to disentangle possible causal effects. This is the main purpose of the rest of the paper.

\section{Legal and Employment Assimilation}

This section analyzes the differences in legal and employment assimilation by country of origin. Three types of outcomes are discussed: (1) legal status at survey date; (2) employment status at survey date; and (3) earnings at survey date. Because of important social, economic and cultural differences between men and women, the analysis is done separately for the two groups.

\section{Employment and Legal Assimilation}

Clearly the decision to work and the choice of legal status are heavily interrelated. Illegal migrants may find it more difficult to find a job or a job that matches their skills. 
As a consequence, many illegal migrants may decide not to work or not to accept certain types of jobs. Conversely, because of their precarious situation, being illegal may lower migrants' reservation wage and prompt them to accept any type of job. At the same time, having a job (even one in the black market) has been one of the administrative requisites for obtaining legal status during the amnesties in Spain. Moreover, to maintain legal status, many migrants have to periodically show proof of employment. Because of this, we estimate a bivariate probit model in which the two LHS variables are dummies indicating whether the individual works and whether she has legal status at survey date.

The model consists of two simultaneous equations, one for the binary decision to have legal status or not, $\mathrm{Y}_{1 \mathrm{i}}$, and another for the binary decision to work or not, $\mathrm{Y}_{2 \mathrm{i}}$. Let the superscript ${ }^{*}$ indicate an unobserved variable and assume that $Y_{1 i}^{*}$ and $Y_{2 i}^{*}$ are as follows:

$$
\begin{aligned}
& Y_{1 i}^{*}=\alpha_{10}+\alpha_{11} X_{1 i}^{1}+\alpha_{12} X_{1 i}^{2}+\alpha_{13} X_{1 i}^{3}+\alpha_{14} X_{1 i}^{4}+\varepsilon_{1 i} \\
& Y_{1 i}=1 \quad \text { if } Y_{1 i}^{*}>0 \\
& Y_{1 i}=0 \text { otherwise } \\
& Y_{2 i}^{*}=\alpha_{20}+\alpha_{21} X_{2 i}^{1}+\alpha_{22} X_{2 i}^{2}+\alpha_{23} X_{2 i}^{3}+\alpha_{24} X_{2 i}^{4}+\varepsilon_{2 i} \\
& Y_{2 i}=1 \quad \text { if } Y_{2 i}^{*}>0 \\
& Y_{2 i}=0 \text { otherwise } \quad \text { for } i=1,2, \ldots, \mathrm{N}
\end{aligned}
$$

where $\operatorname{Cov}\left(\varepsilon_{1 \mathrm{i}}, \varepsilon_{2 \mathrm{i}}\right) \neq 0$. In other words, the errors in each model consist of a part $\left(\eta_{\mathrm{i}}\right)$ that is unique to that model, and a second part $\left(\theta_{\mathrm{i}}\right)$ that is common to both:

$$
\begin{aligned}
& \varepsilon_{1 i}=\eta_{1 i}+\theta_{i} \\
& \varepsilon_{2 i}=\eta_{2 i}+\theta_{i}
\end{aligned}
$$


The disturbances $\varepsilon_{j i}, j=1,2$ are assumed to be zero-mean, bivariate normal distributed with unit variances and a correlation coefficient $\rho$, where $\rho$ is a "correlation parameter" denoting the extent to which the two $\varepsilon_{j i}, j=1,2$, covary.

$\mathrm{X}_{\mathrm{ji}}{ }^{1}, j=1,2$, is a vector including a dummy variable set to 1 if the individual arrived from Morocco (and 0 if she arrived from Ecuador or Romania); $\mathrm{X}_{\mathrm{ji}}{ }^{2}, j=1,2$, is a vector of cohort of arrival dummies (grouping intervals of 5 years); $\mathrm{X}_{\mathrm{ji}}{ }^{3}, j=1,2$, is a vector of covariates that include years since migration (YSM), its square, and both variables interacted by the country of origin dummy; and $\mathrm{X}_{\mathrm{ji}}{ }^{4}, j=1,2$, represents a vector of covariates that include state of residence, age dummies, education dummies, marital status and household size, employment status in prior to emigrating, employment status at arrival, having co-ethnic and Spanish networks at arrival or at survey date, and being fluent in Spanish. First, it is important to highlight the richness of our dataset, which contains employment information in the origin country, and at arrival, as well as information on networks. ${ }^{2}$ Second, while we are not exploiting the panel structure of this dataset, we are controlling for their employment status at arrival. ${ }^{3}$

The model is estimated twice with two different samples. First, we estimate the model with Moroccans and Ecuadorians. Second, we estimate the model with Moroccans and Romanians. The coefficients and standard errors of key variables from models (1) and (2) are shown in Table 3.A (3.B) when comparing Moroccans to Ecuadorians (Romanians) (Panel A for men and Panel B for women). Columns (1) through (5) display different specifications in which we sequentially add different controls: (1) cohort of arrival and state dummies; (2) socio-demographic characteristics;

\footnotetext{
${ }^{2}$ The richness of our dataset contrast with that of other papers in this literature, such as Aydemir, 2011, or de Silva, 1997.

${ }^{3}$ We could construct a panel similar to the one in Aydemir, 2011, where we observe employment status at arrival and at survey date. We decided not to do so in this paper because we want to be able to estimate simultaneously employment and legal assimilation. Unfortunately, legal status at arrival is not observed.
} 
(3) previous employment history (both in Morocco and at arrival to Spain); (4) network effects; and (5) Spanish fluency. We can look at the coefficients and standard errors to gauge direction and statistical significance of individual variable effects, and to see how these change as additional covariates are added into the model.

However, to analyze the effect of country of origin on employment and legal assimilation, we estimate predicted joint probabilities for four possible outcomes: $\operatorname{Pr}\left(\mathrm{Y}_{1 \mathrm{i}}=1, \mathrm{Y}_{2 \mathrm{i}}=1\right) ; \operatorname{Pr}\left(\mathrm{Y}_{1 \mathrm{i}}=1, \mathrm{Y}_{2 \mathrm{i}}=0\right) ; \operatorname{Pr}\left(\mathrm{Y}_{1 \mathrm{i}}=0, \mathrm{Y}_{2 \mathrm{i}}=1\right)$; and $\operatorname{Pr}\left(\mathrm{Y}_{1 \mathrm{i}}=0, \mathrm{Y}_{2 \mathrm{i}}=0\right)$ using the estimated coefficients from the bivariate probit model. These predicted joint probabilities are calculated by country of origin and at different years since arrival for a representative individual type of each gender: a migrant living in Madrid, who arrived in the 1990s, aged 35 to 44 years old, fluent in Spanish, currently married, with primary education or without education, living in a household with 4 members, working at origin, without a job at arrival and with no networks. These predicted joint probabilities are graphed in Figure 1. Below we summarize the main results.

As others have found, Figure 1 shows that immigrants come to Spain to work. This holds regardless of sex or legal status. Among men, as many as two thirds of Moroccans and Ecuadorians and four fifths of Romanians work as soon as they arrive to Spain. Overall, the likelihood of working at arrival is even higher among women with more than four fifths of them working at arrival (regardless of their nationality). Another interesting difference emerges across genders. While most Ecuadorian and Moroccan women have a legal status at arrival, about two thirds of Ecuadorian and Moroccan men lack this legal status at arrival. Romanians differ from this pattern in the following way. Most Romanians (regardless of sex) arrive to Spain without legal status albeit working. 
How do migrants assimilate over time? Among male migrants, over time the joint probability of working and having legal status increases converging towards 70 percent 12 years after arrival for the three nationalities of migrants. At the same time the joint likelihood of working and being illegal converges towards zero for Moroccans and Ecuadorians, and towards 20 percent for Romanians. Assimilation into both employment and legal status is fastest among Romanians because they are disproportionately working without having legal status at arrival. This assimilation pattern is consistent with the fact that the easiest way to become legal in Spain is through employment (as one of the main conditions in the amnesties is to have an employer guaranteeing a job).

The story differs among women. For Moroccan and Ecuadorian women, the joint likelihood of both working and having legal status decreases over time from four fifths at arrival to two thirds. In contrast for Romanian women this joint probability increases from close to 30 percent at arrival to 40 percent ten years after arrival.

The joint likelihood of not working but having legal status at arrival ranges between 10 percent and 20 percent for Moroccans and Ecuadorians at arrival, and within less than a decade converges to 30 percent. In contrast, this joint likelihood is practically zero at arrival and converges to 10 percent among males and 5 percent among women. Among males the joint probability of not working and not being legal at arrival ranges between 20 percent and 30 percent, but within a decade it converges to 5 percent. This joint likelihood is practically inexistent among women.

Summing up, we observe that once all observable characteristics are controlled for, male migrants have a similar labor and legal assimilation pattern in Spain regardless of their nationalities (with Romanians faring worse in terms of legal status but better in terms of employment status at arrival). Among women, Moroccans and Ecuadorians 
follow a similar pattern that contrasts with that of Romanian women. While the former mainly arrive to Spain to work with legal status, and, with time in Spain, (some of them) move out of employment; the latter are considerably (and persistently) more attached to the labor force, although they tend to lack legal status at arrival, and only gain such status overtime.

\section{Wage Assimilation}

When analyzing earnings, we use model (4) below with a log-linear specification and log earnings as the LHS variable.

$$
Y_{i}=\alpha_{0}+\alpha_{1} X_{i}^{1}+\alpha_{2} X_{i}^{2}+\alpha_{3} X_{i}^{3}+\alpha_{4} X_{i}^{4}+\varepsilon_{i}
$$

where $\mathrm{X}_{\mathrm{i}}^{1}$ is a vector including a dummy variable set to 1 if the individual arrived in Spain from Morocco (and 0 otherwise); $\mathrm{X}_{\mathrm{i}}^{2}$ is a vector of cohort of arrival dummies (grouping intervals of 5 years); $\mathrm{X}_{\mathrm{i}}^{3}$ is a vector of covariates that include years since migration (YSM), its square, and both variables interacted by the Moroccan dummy; and $\mathrm{X}_{\mathrm{i}}^{4}$ represents a vector of covariates that include state of residence, age dummies, education dummies, marital status and household size, employment status prior to emigrating, employment status at arrival, having co-ethnic and Spanish networks at arrival or at survey date, and being fluent in Spanish.

In addition, to account for possible selection bias arising from not accounting for individual's choice of whether to work or not, we use a Heckman selection bias correction. To do this, we first estimate the probability of working at survey date for all individuals in the data set. The probability that an individual worked is modeled as a function of age, the number of children and the age of the youngest child in the household, marital status, work experience, education, state of residence, tenant or house-ownership status, and living in a municipality with less than 5000 inhabitants. From this equation, we estimate the inverse Mills ratio, and use it as an additional independent variable in the earnings equation. Our source of identification that appears 
in the selection equation but not the wage equation includes: having children, age of youngest child, tenant or house-ownership status, and living in a municipality with less than 5000 inhabitants. ${ }^{4}$ We argue that correcting for the migrant's employment decision is particularly relevant in this analysis because we have observed statistically significant employment differences by country of arrival, especially between Romanians and the other two nationalities. ${ }^{5}$ Again, the analysis is done separately by gender. Results are presented in Tables 4.A and 4.B.

Focusing first in Table 4.A, we observe that OLS estimates indicate that Moroccan males earn $18 \log$ points lower wages than Ecuadorians at arrival prior to adding controls in the model. Adding controls to the OLS specification decreases the wage differential by one third. However, the Heckman corrected estimates of the Moroccan dummy becomes a statistically significant positive 7 log points, suggesting that failure to account for the employment decision leads to a downward bias of the country effect between Moroccans and Ecuadorians. A bias in the same direction but of smaller magnitude is observed among women. Similarly, while the OLS estimates indicated that the YSM profile increases for Ecuadorian males and is flat for Moroccan males, the Heckman correction estimates suggest that the YSM profile is downward sloped for Ecuadorian males and flat for Moroccans. For women, the Heckman correction reveals a flat YSM profile for Ecuadorians and a upward sloping YSM profile for Moroccans.

Table 4.B reveals that the selection bias has the opposite sign when Moroccan and Romanian males are analyzed. While this may seem puzzling the large differences

\footnotetext{
${ }^{4}$ Finding good instruments is difficult. Having children is a commonly used instrument, although it may be correlated with wages. Alternatively our variable on tenant or ownership status is probably a better instrument. Nonetheless, because of concerns with endogeneity of our instruments we estimated the OLS wage model including these variables as controls. When doing so, most of the coefficients of interest remain unaffected.

${ }^{5}$ Although assimilation patterns between Moroccans and Ecuadorians are similar, the Moroccan dummy and the interactions of this dummy with YSM are statistically significantly different (as show in Table 3.A).
} 
in employment patterns across these two groups of migrants are likely to be the reason behind this.

Summing up, these results suggest that Moroccan males outperform Ecuadorian males in terms of higher wages at arrival. Moreover, Table 4.A suggests that earnings convergence does not occur as the wage differential increases over time. A similar pattern is observed between Moroccan and Romanian women, with the former outperforming the latter in terms of higher wages at arrival and lack of converge with time in Spain. Among women, we observe a similar wage advantage of Moroccan women relative to Ecuadorians in terms of growth over time (but not in terms of wage differential at arrival). In contrast, the story is quite different between Moroccan and Romanian man. Once employment selection is accounted for with Heckman correction, there are no differences in wages across these two groups of migrants.

\section{Conclusion}

Over the second half of the 20th century, Morocco, Ecuador and Romania have evolved into some of the world's leading emigration countries, and Spain has become one of their preferred destinations. Understanding the labor market assimilation of low-skilled (often irregular) migrants is of great policy relevance not only for economic, but also for social reasons. Exploiting the rich information from the 2007 Encuesta Nacional de Immigración (ENI), which reports on labor market outcomes before and after arrival in the host country, we study the settlement process of Moroccans, Ecuadorians and Romanians in Spain focusing on their similarities and differences. More specifically, our analysis studies whether the country of origin affects labor market and legal status assimilation. 
First, our analysis finds that, once all observable characteristics are controlled for, male migrants follow a similar labor and legal assimilation pattern in Spain regardless of their nationality (with Romanians faring worse in terms of legal status but better in terms of employment status at arrival). Among women, Moroccans and Ecuadorians follow a similar pattern that contrasts with that of Romanian women. While the former mainly arrive to Spain with legal status and to work and eventually (some of them) converge out of employment, the latter are considerably (and persistently) more attached to the labor force, and overtime they gain legal status.

Once we control for observable characteristics and use Heckman selection estimates, our wage analysis finds that with the exception of Moroccan and Romanian males for which no wage differences are observed, Moroccans outperform the other two nationalities either in terms of higher wages at arrival. Moreover, most frequently this wage differential increases over time. A concern with our analysis is that we cannot correct for return migration. Nevertheless, because the richness of the data enables us to control for important characteristics, such as migrant's employment prior to migrating, we present estimates that are potentially less biased than those previously presented using cross-sectional data.

\section{REFERENCES}

Amuedo-Dorantes C., De la Rica S. 2007. "Labor Market Assimilation in Spain." British Journal of Industrial Relations 45:2: 0007-1080 pp. 257-284.

Alcobendas M., and N. Rodríguez-Planas. 2009. "Occupational Assimilation After a Recent Immigration Boom.” IZA discussion paper No. 4394.

Aydemir A., 2009. "Immigrant Selection and Short-Term Labor Market Outcomes by Visa Category." Journal of Population Economics, 24: 451-475. 
Bertoli S., J. Fernandez-Huertas Moraga, and Francesc Ortega, 2011. "Immigration Policies and the Ecuadorian Exodus," World Bank Economic Review, Oxford University Press, vol. 25(1), pages 57-76, March

De Silva A., 1997, "Earnings of Immigrant Classes in the Early 1980s in Canada: a Reexamination." Canadian Public Policy, 23, 2: 179-202.

Dolado, J., and Vázquez P. 2007. "Los Efectos Económicos y las Políticas de la Inmigración: Panorámica y Reflexiones.” FEDEA Working Paper.

Dueñas Fernández, Iglesias Fernández, and R. Llorente. 2010. "La Asimilación Laboral de los Inmigrantes Rumanos y Búlgaros en España: ¿Es Importante el Cambio en su Status Laboral?" working paper.

Fernández, C. and C. Ortega. 2008. "Labor market assimilation of immigrants in Spain: Employment at the Expense of Bad Job-Matches?", Spanish Economic Review, vol. 10, n. 2, pp. 83-107.

Foroutan, Y. 2008b. "Employment Differentials of Second Generation Muslim Migrants: Assimilation and Discrimination Hypotheses." Immigrants \& Minorities 26(3):1-23.

Foroutan, Y. 2008c. "Gender, Religion and Work: Comparative Analysis of South Asian Migrants." Fieldwork in Religion 3(1):29-50.

Izquierdo M., Lacuesta A., Vegas R. 2009. "Assimilation of Immigrants in Spain: a Longitudinal Analysis.” Labour Economics.

McQuilan, K. 2004 “When Does Religion Influence Fertility?', Population and Development Review 30(1): 25-56.

Omran, A. R., and F. Roudi. 1993 “The Middle East Population Puzzle.'” Population Bulletin 48(1):1-38.

Rodríguez-Planas, N., and R. Vegas. 2011. "Moroccans' Assimilation in Spain. Family-based versus Labor-based Migrants." Middle East Development Journal, vol. 3, issue 2: 119-139.

Sanromá E., R. Ramos, and H. Simó. 2009. "Immigrant Wages in the Spanish Labour Market: Does the Origin of Huma Capital Matter?" IZA Discussion Paper No. 4157. 
Table 1. Moroccans versus Ecuadorians and Romanians in Spain in 2007 (Percent unless otherwise stated)

\begin{tabular}{|c|c|c|c|c|c|c|}
\hline & \multicolumn{2}{|c|}{ Moroccans } & \multicolumn{2}{|c|}{ Ecuadorians } & \multicolumn{2}{|c|}{ Romanians } \\
\hline & Males & Females & Males & Females & Males & Females \\
\hline Current age (mean) & $\begin{array}{l}36.279 \\
(8.84)\end{array}$ & $\begin{array}{c}34.769 \\
(10.035)\end{array}$ & $\begin{array}{l}36.372 \\
(8.884)\end{array}$ & $\begin{array}{l}34.702 \\
(8.317)\end{array}$ & $\begin{array}{l}33.155 \\
(7.914)\end{array}$ & $\begin{array}{l}31.873 \\
(8.49)\end{array}$ \\
\hline Year of arrival (median) & $\begin{array}{c}1999 \\
(10.103)\end{array}$ & $\begin{array}{c}1998 \\
(12.181)\end{array}$ & $\begin{array}{l}2000 \\
(2.355)\end{array}$ & $\begin{array}{l}2000 \\
(2.181)\end{array}$ & $\begin{array}{l}2003 \\
(2.647)\end{array}$ & $\begin{array}{l}2003 \\
(2.23)\end{array}$ \\
\hline Years since arrival(median) & $\begin{array}{c}8.000 \\
(10.103)\end{array}$ & $\begin{array}{c}9.000 \\
(12.181)\end{array}$ & $\begin{array}{l}7.000 \\
(2.355)\end{array}$ & $\begin{array}{l}7.000 \\
(2.181)\end{array}$ & $\begin{array}{l}4.000 \\
(2.647)\end{array}$ & $\begin{array}{l}4.000 \\
(2.23)\end{array}$ \\
\hline Age at arrival (mean) & $\begin{array}{l}25.178 \\
(8.909)\end{array}$ & $\begin{array}{l}22.557 \\
(9.872)\end{array}$ & $\begin{array}{l}30.567 \\
(8.682)\end{array}$ & $\begin{array}{c}28.947 \\
(8.2)\end{array}$ & $\begin{array}{l}29.350 \\
(7.695)\end{array}$ & $\begin{array}{l}28.581 \\
(8.33)\end{array}$ \\
\hline Primary & $\begin{array}{c}0.572 \\
(0.495)\end{array}$ & $\begin{array}{l}0.517 \\
(0.5)\end{array}$ & $\begin{array}{l}0.375 \\
(0.484)\end{array}$ & $\begin{array}{c}0.324 \\
(0.468)\end{array}$ & $\begin{array}{c}0.174 \\
(0.379)\end{array}$ & $\begin{array}{c}0.177 \\
(0.382)\end{array}$ \\
\hline HS dropouts & $\begin{array}{c}0.155 \\
(0.362)\end{array}$ & $\begin{array}{c}0.165 \\
(0.371)\end{array}$ & $\begin{array}{c}0.142 \\
(0.349)\end{array}$ & $\begin{array}{c}0.146 \\
(0.353)\end{array}$ & $\begin{array}{c}0.256 \\
(0.436)\end{array}$ & $\begin{array}{l}0.214 \\
(0.41)\end{array}$ \\
\hline HS graduate & $\begin{array}{c}0.198 \\
(0.399)\end{array}$ & $\begin{array}{c}0.224 \\
(0.417)\end{array}$ & $\begin{array}{c}0.404 \\
(0.491)\end{array}$ & $\begin{array}{c}0.398 \\
(0.489)\end{array}$ & $\begin{array}{c}0.505 \\
(0.5)\end{array}$ & $\begin{array}{l}0.479 \\
(0.5)\end{array}$ \\
\hline University degree & $\begin{array}{c}0.075 \\
(0.263)\end{array}$ & $\begin{array}{c}0.094 \\
(0.292)\end{array}$ & $\begin{array}{l}0.079 \\
(0.27)\end{array}$ & $\begin{array}{c}0.132 \\
(0.338)\end{array}$ & $\begin{array}{c}0.065 \\
(0.247)\end{array}$ & $\begin{array}{c}0.129 \\
(0.336)\end{array}$ \\
\hline Spanish fluency & $\begin{array}{c}0.568 \\
(0.495)\end{array}$ & $\begin{array}{c}0.602 \\
(0.489)\end{array}$ & 0.1 & 0.1 & $\begin{array}{c}0.667 \\
(0.471)\end{array}$ & $\begin{array}{c}0.736 \\
(0.441)\end{array}$ \\
\hline Married & $\begin{array}{c}0.613 \\
(0.487)\end{array}$ & $\begin{array}{c}0.633 \\
(0.482)\end{array}$ & $\begin{array}{c}0.435 \\
(0.496)\end{array}$ & $\begin{array}{c}0.379 \\
(0.485)\end{array}$ & $\begin{array}{c}0.479 \\
(0.5)\end{array}$ & $\begin{array}{c}0.538 \\
(0.499)\end{array}$ \\
\hline Couple & $\begin{array}{c}0.449 \\
(0.497)\end{array}$ & $\begin{array}{l}0.584 \\
(0.493)\end{array}$ & $\begin{array}{l}0.327 \\
(0.469)\end{array}$ & $\begin{array}{l}0.308 \\
(0.462)\end{array}$ & $\begin{array}{c}0.423 \\
(0.494)\end{array}$ & $\begin{array}{l}0.483 \\
(0.5)\end{array}$ \\
\hline Number of persons in household & $\begin{array}{c}4.151 \\
(2.218)\end{array}$ & $\begin{array}{l}4.211 \\
(2.123)\end{array}$ & $\begin{array}{c}4.298 \\
(1.716)\end{array}$ & $\begin{array}{l}4.000 \\
(1.703)\end{array}$ & $\begin{array}{l}3.934 \\
(2.049)\end{array}$ & $\begin{array}{c}3.986 \\
(1.898)\end{array}$ \\
\hline Working in origin country & $\begin{array}{c}0.429 \\
(0.495)\end{array}$ & $\begin{array}{c}0.332 \\
(0.471)\end{array}$ & $\begin{array}{c}0.610 \\
(0.488)\end{array}$ & $\begin{array}{c}0.555 \\
(0.497)\end{array}$ & $\begin{array}{l}0.605 \\
(0.489)\end{array}$ & $\begin{array}{l}0.599 \\
(0.49)\end{array}$ \\
\hline $\begin{array}{l}\text { Had a job before leaving country of } \\
\text { origin } \\
\text { Was working within } 30 \text { days after }\end{array}$ & $\begin{array}{c}0.098 \\
(0.297) \\
0.452\end{array}$ & $\begin{array}{l}0.116 \\
(0.32) \\
0.475\end{array}$ & $\begin{array}{c}0.091 \\
(0.288) \\
0.540\end{array}$ & $\begin{array}{l}0.093 \\
(0.29) \\
0.609\end{array}$ & $\begin{array}{c}0.145 \\
(0.352) \\
0.518\end{array}$ & $\begin{array}{l}0.125 \\
(0.33) \\
0.514\end{array}$ \\
\hline $\begin{array}{l}\text { Was working within } 30 \text { days after } \\
\text { arrival to Spain } \\
\text { How many times have you visited the }\end{array}$ & $\begin{array}{c}0.452 \\
(0.498) \\
11.860\end{array}$ & $\begin{array}{c}0.475 \\
(0.499) \\
14.845\end{array}$ & $\begin{array}{c}0.540 \\
(0.498) \\
1.577\end{array}$ & $\begin{array}{c}0.609 \\
(0.488) \\
2.418\end{array}$ & $\begin{array}{l}0.518 \\
(0.5) \\
2.631\end{array}$ & $\begin{array}{l}0.514 \\
(0.5) \\
1.584\end{array}$ \\
\hline country since coming to Spain (mean) & $(25.63)$ & $(28.156)$ & $(8.425)$ & $(11.311)$ & $(10.704)$ & $(3.388)$ \\
\hline Participates in co-ethnic associations & $\begin{array}{c}0.055 \\
(0.228)\end{array}$ & $\begin{array}{l}0.062 \\
(0.24)\end{array}$ & $\begin{array}{l}0.048 \\
(0.214)\end{array}$ & $\begin{array}{c}0.057 \\
(0.232)\end{array}$ & $\begin{array}{l}0.044 \\
(0.204)\end{array}$ & $\begin{array}{c}0.063 \\
(0.243)\end{array}$ \\
\hline Participate in Spanish associations & $\begin{array}{c}0.090 \\
(0.286)\end{array}$ & $\begin{array}{c}0.103 \\
(0.304)\end{array}$ & $\begin{array}{c}0.104 \\
(0.306)\end{array}$ & $\begin{array}{c}0.095 \\
(0.293)\end{array}$ & $\begin{array}{c}0.068 \\
(0.251)\end{array}$ & $\begin{array}{c}0.082 \\
(0.274)\end{array}$ \\
\hline Someone known in Spain at arrival & $\begin{array}{c}0.650 \\
(0.477)\end{array}$ & $\begin{array}{c}0.633 \\
(0.482)\end{array}$ & $\begin{array}{c}0.815 \\
(0.388)\end{array}$ & $\begin{array}{l}0.884 \\
(0.32)\end{array}$ & $\begin{array}{c}0.830 \\
(0.376)\end{array}$ & $\begin{array}{c}0.851 \\
(0.357)\end{array}$ \\
\hline $\begin{array}{l}\text { Sample size } \\
\text { Population size }\end{array}$ & $\begin{array}{c}880 \\
100431\end{array}$ & $\begin{array}{c}468 \\
48564\end{array}$ & $\begin{array}{c}512 \\
50695\end{array}$ & $\begin{array}{c}613 \\
63297\end{array}$ & $\begin{array}{c}552 \\
61742\end{array}$ & $\begin{array}{c}611 \\
63463\end{array}$ \\
\hline
\end{tabular}

Note: All means have been weighted at the population level. Standard deviations in parentheses. Only people aged between 1955 years old have been considered. 
Table 2. Moroccans, Ecuadorians and Romanians in Spain in 2007 Selected Outcome Variables

\begin{tabular}{|c|c|c|c|c|c|c|}
\hline & \multicolumn{2}{|c|}{ Moroccans } & \multicolumn{2}{|c|}{ Ecuadorians } & \multicolumn{2}{|c|}{ Romanians } \\
\hline & Males & Females & Males & Females & Males & Females \\
\hline Currently legal resident & $\begin{array}{r}0.881 \\
(0.324) \\
\end{array}$ & $\begin{array}{c}0.898 \\
(0.302) \\
\end{array}$ & $\begin{array}{r}0.902 \\
(0.298) \\
\end{array}$ & $\begin{array}{c}0.893 \\
(0.309) \\
\end{array}$ & $\begin{array}{r}0.572 \\
(0.495) \\
\end{array}$ & $\begin{array}{l}0.600 \\
(0.49) \\
\end{array}$ \\
\hline Working last week & $\begin{array}{c}0.612 \\
(0.487)\end{array}$ & $\begin{array}{c}0.526 \\
(0.499)\end{array}$ & $\begin{array}{c}0.783 \\
(0.412)\end{array}$ & $\begin{array}{c}0.780 \\
(0.414)\end{array}$ & $\begin{array}{c}0.753 \\
(0.431)\end{array}$ & $\begin{array}{c}0.749 \\
(0.434)\end{array}$ \\
\hline Monthly Wages & $\begin{array}{l}1074.621 \\
(467.609)\end{array}$ & $\begin{array}{c}954.651 \\
(528.904)\end{array}$ & $\begin{array}{c}980.043 \\
(304.797)\end{array}$ & $\begin{array}{l}897.805 \\
(330.099)\end{array}$ & $\begin{array}{l}951.518 \\
(380.043)\end{array}$ & $\begin{array}{c}904.086 \\
(463.276)\end{array}$ \\
\hline $\begin{array}{l}\text { Sample size } \\
\text { Population size }\end{array}$ & $\begin{array}{c}880 \\
100431\end{array}$ & $\begin{array}{r}468 \\
48564 \\
\end{array}$ & $\begin{array}{r}512 \\
50695 \\
\end{array}$ & $\begin{array}{r}613 \\
63297 \\
\end{array}$ & $\begin{array}{r}552 \\
61742 \\
\end{array}$ & $\begin{array}{r}611 \\
63463 \\
\end{array}$ \\
\hline
\end{tabular}

Note: All means have been weighted at the population level. Standard deviations in parentheses. Only people aged between 19-55 years old have been considered. Source: National Immigrant Survey (ENI 2007) 
Table 3.A. Bivariate Probit Model. Moroccans versus Ecuadoreans 19 to 55 Years Old in Spain.

\begin{tabular}{|c|c|c|c|c|c|c|c|c|c|c|}
\hline & \multicolumn{5}{|c|}{ Panel A: Males } & \multicolumn{5}{|c|}{ Panel B: Females } \\
\hline & $(1)$ & $(2)$ & (3) & (4) & $(5)$ & $(6)$ & $(7)$ & $(8)$ & $(9)$ & $(10)$ \\
\hline & $\begin{array}{c}\text { Cohort } \\
\text { dummies }+ \\
\text { CCAA }\end{array}$ & $\begin{array}{c}\text { Demographic } \\
\text { characteristics }\end{array}$ & Employment & Networks & $\begin{array}{l}\text { Spanish } \\
\text { fluent }\end{array}$ & $\begin{array}{c}\text { Cohort } \\
\text { dummies }+ \\
\text { CCAA }\end{array}$ & $\begin{array}{c}\text { Demographic } \\
\text { characteristics }\end{array}$ & Employment & Networks & $\begin{array}{c}\text { Spanish } \\
\text { fluent }\end{array}$ \\
\hline & \multicolumn{10}{|c|}{ Dependent variable: Legal status } \\
\hline Moroccan & $\begin{array}{c}-1.513 * * * \\
(0.055)\end{array}$ & $\begin{array}{c}-1.260 * * * \\
(0.057)\end{array}$ & $\begin{array}{c}-1.171 * * * \\
(0.056)\end{array}$ & $\begin{array}{c}-1.224 * * * \\
(0.057)\end{array}$ & $\begin{array}{c}-1.335^{* * *} \\
(0.058)\end{array}$ & $\begin{array}{c}0.307 * * * \\
(0.058)\end{array}$ & $\begin{array}{c}0.453 * * * \\
(0.058)\end{array}$ & $\begin{array}{c}0.541 * * * \\
(0.056)\end{array}$ & $\begin{array}{c}0.522 * * * \\
(0.056)\end{array}$ & $\begin{array}{c}0.454 * * * \\
(0.057)\end{array}$ \\
\hline Moroccan * Ysm & $\begin{array}{c}0.299 * * * \\
(0.016)\end{array}$ & $\begin{array}{c}0.224 * * * \\
(0.017)\end{array}$ & $\begin{array}{c}0.189 * * * \\
(0.016)\end{array}$ & $\begin{array}{c}0.209 * * * \\
(0.016)\end{array}$ & $\begin{array}{c}0.209 * * * \\
(0.017)\end{array}$ & $\begin{array}{c}-0.037 * * \\
(0.017)\end{array}$ & $\begin{array}{c}-0.113^{* * *} \\
(0.016)\end{array}$ & $\begin{array}{c}-0.135^{* * *} \\
(0.015)\end{array}$ & $\begin{array}{c}-0.131 * * * \\
(0.015)\end{array}$ & $\begin{array}{c}-0.132 * * * \\
(0.015)\end{array}$ \\
\hline Moroccan * Ysm ${ }^{2}$ & $\begin{array}{c}-0.015 * * * \\
(0.001)\end{array}$ & $\begin{array}{c}-0.012 * * * \\
(0.001)\end{array}$ & $\begin{array}{c}-0.009^{* * *} \\
(0.001)\end{array}$ & $\begin{array}{c}-0.011 * * * \\
(0.001)\end{array}$ & $\begin{array}{c}-0.011 * * * \\
(0.001)\end{array}$ & $\begin{array}{c}-0.003 * * * \\
(0.001)\end{array}$ & $\begin{array}{c}0.002 \\
(0.001)\end{array}$ & $\begin{array}{c}0.003 * * * \\
(0.001)\end{array}$ & $\begin{array}{c}0.004 * * * \\
(0.001)\end{array}$ & $\begin{array}{c}0.004 * * * \\
(0.001)\end{array}$ \\
\hline \multirow{3}{*}{$\mathrm{Ysm}^{2}$} & $\begin{array}{c}0.062 * * * \\
(0.016)\end{array}$ & $\begin{array}{c}0.162 * * * \\
(0.017)\end{array}$ & $\begin{array}{c}0.202 * * * \\
(0.016)\end{array}$ & $\begin{array}{c}0.177 * * * \\
(0.017)\end{array}$ & $\begin{array}{c}0.163 * * * \\
(0.017)\end{array}$ & $\begin{array}{c}0.071 * * * \\
(0.017)\end{array}$ & $\begin{array}{c}0.155^{* * *} \\
(0.016)\end{array}$ & $\begin{array}{c}0.181 * * * \\
(0.016)\end{array}$ & $\begin{array}{c}0.181 * * * \\
(0.015)\end{array}$ & $\begin{array}{c}0.183 * * * \\
(0.015)\end{array}$ \\
\hline & $\begin{array}{c}0.004 * * * \\
(0.001) \\
\end{array}$ & $\begin{array}{r}0.001 \\
(0.001) \\
\end{array}$ & $\begin{array}{l}-0.002 \\
(0.001) \\
\end{array}$ & $\begin{array}{l}-0.000 \\
(0.001) \\
\end{array}$ & $\begin{array}{c}0.000 \\
(0.001) \\
\end{array}$ & $\begin{array}{c}0.003 * * \\
(0.001) \\
\end{array}$ & $\begin{array}{c}-0.003 * * \\
(0.001) \\
\end{array}$ & $\begin{array}{c}-0.004^{* * *} \\
(0.001) \\
\end{array}$ & $\begin{array}{c}-0.005^{* * *} \\
(0.001) \\
\end{array}$ & $\begin{array}{c}-0.005^{* * *} \\
(0.001) \\
\end{array}$ \\
\hline & \multicolumn{10}{|c|}{ Dependent variable: Employment status } \\
\hline Moroccan & $\begin{array}{c}-0.767 * * * \\
(0.038)\end{array}$ & $\begin{array}{c}-0.739 * * * \\
(0.038)\end{array}$ & $\begin{array}{c}-0.568 * * * \\
(0.039)\end{array}$ & $\begin{array}{c}-0.591 * * * \\
(0.039)\end{array}$ & $\begin{array}{c}-0.641 * * * \\
(0.040)\end{array}$ & $\begin{array}{c}-0.873 * * * \\
(0.038)\end{array}$ & $\begin{array}{c}-0.744 * * * \\
(0.039)\end{array}$ & $\begin{array}{c}-0.679 * * * \\
(0.039)\end{array}$ & $\begin{array}{c}-0.706^{* * *} \\
(0.040)\end{array}$ & $\begin{array}{c}-0.732 * * * \\
(0.041)\end{array}$ \\
\hline Moroccan * Ysm & $\begin{array}{c}0.056^{* * *} \\
(0.008)\end{array}$ & $\begin{array}{c}0.030 * * * \\
(0.008)\end{array}$ & $\begin{array}{l}-0.012 \\
(0.009)\end{array}$ & $\begin{array}{l}-0.009 \\
(0.009)\end{array}$ & $\begin{array}{l}-0.008 \\
(0.009)\end{array}$ & $\begin{array}{l}0.016^{*} \\
(0.008)\end{array}$ & $\begin{array}{l}-0.009 \\
(0.009)\end{array}$ & $\begin{array}{l}-0.011 \\
(0.009)\end{array}$ & $\begin{array}{l}-0.009 \\
(0.009)\end{array}$ & $\begin{array}{l}-0.010 \\
(0.009)\end{array}$ \\
\hline Moroccan $* \mathrm{Ysm}^{2}$ & $\begin{array}{c}-0.001 * * * \\
(0.000)\end{array}$ & $\begin{array}{l}0.001 * * \\
(0.000)\end{array}$ & $\begin{array}{c}0.004 * * * \\
(0.000)\end{array}$ & $\begin{array}{c}0.004 * * * \\
(0.000)\end{array}$ & $\begin{array}{c}0.004 * * * \\
(0.000)\end{array}$ & $\begin{array}{c}0.002 * * * \\
(0.000)\end{array}$ & $\begin{array}{c}0.003 * * * \\
(0.000)\end{array}$ & $\begin{array}{c}0.003 * * * \\
(0.000)\end{array}$ & $\begin{array}{c}0.003^{* * *} \\
(0.000)\end{array}$ & $\begin{array}{c}0.003 * * * \\
(0.000)\end{array}$ \\
\hline Ysm & $\begin{array}{c}-0.081 * * * \\
(0.009)\end{array}$ & $\begin{array}{c}-0.023 * * * \\
(0.009)\end{array}$ & $\begin{array}{c}0.034 * * * \\
(0.009)\end{array}$ & $\begin{array}{c}0.026^{* * *} \\
(0.009)\end{array}$ & $\begin{array}{c}0.023 * * \\
(0.009)\end{array}$ & $\begin{array}{c}-0.018 * * \\
(0.009)\end{array}$ & $\begin{array}{l}0.016^{*} \\
(0.009)\end{array}$ & $\begin{array}{c}0.024 * * * \\
(0.009)\end{array}$ & $\begin{array}{l}0.017 * \\
(0.009)\end{array}$ & $\begin{array}{c}0.018 * * \\
(0.009)\end{array}$ \\
\hline $\mathrm{Ysm}^{2}$ & $\begin{array}{c}0.002 * * * \\
(0.000)\end{array}$ & $\begin{array}{c}-0.001 * * \\
(0.000)\end{array}$ & $\begin{array}{c}-0.004 * * * \\
(0.000)\end{array}$ & $\begin{array}{c}-0.004 * * * \\
(0.000)\end{array}$ & $\begin{array}{c}-0.004 * * * \\
(0.000)\end{array}$ & $\begin{array}{c}-0.002 * * * \\
(0.000)\end{array}$ & $\begin{array}{c}-0.003 * * * \\
(0.000)\end{array}$ & $\begin{array}{c}-0.004 * * * \\
(0.000)\end{array}$ & $\begin{array}{c}-0.004 * * * \\
(0.000)\end{array}$ & $\begin{array}{c}-0.004 * * * \\
(0.000)\end{array}$ \\
\hline Unweighted sample size & & & 1368 & & & & & 1069 & & \\
\hline
\end{tabular}

Note: All specifications include region dummies. $* * * \mathrm{p}<0.01, * * \mathrm{p}<0.05, * \mathrm{p}<0.1$ 
Table 3.B. Bivariate Probit Model. Moroccans versus Romanians 19 to 55 Years Old in Spain

\begin{tabular}{|c|c|c|c|c|c|c|c|c|c|c|}
\hline & \multicolumn{5}{|c|}{ Panel A: Males } & \multicolumn{5}{|c|}{ Panel B: Females } \\
\hline & $(1)$ & $(2)$ & (3) & $(4)$ & $(5)$ & $(1)$ & $(2)$ & $(3)$ & $(4)$ & $(5)$ \\
\hline & $\begin{array}{c}\text { Cohort dummies } \\
+ \text { CCAA }\end{array}$ & $\begin{array}{c}\text { Demographic } \\
\text { characteristics }\end{array}$ & Employment & Networks & $\begin{array}{c}\text { Spanish } \\
\text { fluent }\end{array}$ & $\begin{array}{c}\text { Cohort } \\
\text { dummies }+ \\
\text { CCAA } \\
\end{array}$ & $\begin{array}{c}\text { Demographic } \\
\text { characteristics }\end{array}$ & Employment & Networks & $\begin{array}{c}\text { Spanish } \\
\text { fluent }\end{array}$ \\
\hline & \multicolumn{10}{|c|}{ Dependent variable: Legal status } \\
\hline Moroccan & $\begin{array}{c}1.003 * * * \\
(0.026)\end{array}$ & $\begin{array}{c}1.039 * * * \\
(0.028)\end{array}$ & $\begin{array}{c}1.191 * * * \\
(0.029)\end{array}$ & $\begin{array}{c}1.233 * * * \\
(0.029)\end{array}$ & $\begin{array}{c}1.146^{* * * *} \\
(0.030)\end{array}$ & $\begin{array}{c}2.138 * * * \\
(0.028)\end{array}$ & $\begin{array}{c}2.094 * * * \\
(0.029)\end{array}$ & $\begin{array}{c}2.171 * * * \\
(0.030)\end{array}$ & $\begin{array}{c}2.161 * * * \\
(0.030)\end{array}$ & $\begin{array}{c}2.099 * * * \\
(0.030)\end{array}$ \\
\hline Moroccan ${ }^{*}$ Ysm & $\begin{array}{c}-0.159^{* * * *} \\
(0.007)\end{array}$ & $\begin{array}{c}-0.123 * * * \\
(0.007)\end{array}$ & $\begin{array}{c}-0.158 * * * \\
(0.007)\end{array}$ & $\begin{array}{c}-0.168 * * * \\
(0.008)\end{array}$ & $\begin{array}{c}-0.143^{* * *} \\
(0.008)\end{array}$ & $\begin{array}{c}-0.425 * * * \\
(0.008)\end{array}$ & $\begin{array}{c}-0.376^{* * *} \\
(0.009)\end{array}$ & $\begin{array}{c}-0.389 * * * \\
(0.009)\end{array}$ & $\begin{array}{c}-0.387 * * * \\
(0.009)\end{array}$ & $\begin{array}{c}-0.370 * * * \\
(0.009)\end{array}$ \\
\hline Moroccan $*$ Ysm $^{2}$ & $\begin{array}{c}0.007 * * * \\
(0.000)\end{array}$ & $\begin{array}{c}0.006 * * * \\
(0.000)\end{array}$ & $\begin{array}{c}0.008 * * * \\
(0.000)\end{array}$ & $\begin{array}{c}0.009^{* * *} \\
(0.000)\end{array}$ & $\begin{array}{c}0.008^{* * *} \\
(0.000)\end{array}$ & $\begin{array}{c}0.019 * * * \\
(0.001)\end{array}$ & $\begin{array}{c}0.017 * * * \\
(0.001)\end{array}$ & $\begin{array}{c}0.018^{* * *} \\
(0.001)\end{array}$ & $\begin{array}{c}0.018^{* * *} \\
(0.001)\end{array}$ & $\begin{array}{c}0.017 * * * \\
(0.001)\end{array}$ \\
\hline Ysm & $\begin{array}{c}0.414 * * * \\
(0.006)\end{array}$ & $\begin{array}{c}0.423 * * * \\
(0.007)\end{array}$ & $\begin{array}{c}0.464 * * * \\
(0.007)\end{array}$ & $\begin{array}{c}0.493 * * * \\
(0.007)\end{array}$ & $\begin{array}{c}0.448^{* * *} \\
(0.007)\end{array}$ & $\begin{array}{c}0.438 * * * \\
(0.008)\end{array}$ & $\begin{array}{c}0.412 * * * \\
(0.008)\end{array}$ & $\begin{array}{c}0.427 * * * \\
(0.008)\end{array}$ & $\begin{array}{c}0.433 * * * \\
(0.008)\end{array}$ & $\begin{array}{c}0.414 * * * \\
(0.008)\end{array}$ \\
\hline \multirow[t]{2}{*}{$Y_{s m^{2}}$} & $\begin{array}{c}-0.015^{* * *} \\
(0.000) \\
\end{array}$ & $\begin{array}{c}-0.015^{* * *} \\
(0.000) \\
\end{array}$ & $\begin{array}{c}-0.016^{* * *} \\
(0.000) \\
\end{array}$ & $\begin{array}{c}-0.018^{* * *} \\
(0.000) \\
\end{array}$ & $\begin{array}{c}-0.016^{* * *} \\
(0.000) \\
\end{array}$ & $\begin{array}{c}-0.020^{* * *} \\
(0.001) \\
\end{array}$ & $\begin{array}{c}-0.018^{* * *} \\
(0.001) \\
\end{array}$ & $\begin{array}{c}-0.019 * * * \\
(0.001)\end{array}$ & $\begin{array}{c}-0.019^{* * *} \\
(0.001) \\
\end{array}$ & $\begin{array}{c}-0.018^{* * *} \\
(0.001)\end{array}$ \\
\hline & \multicolumn{10}{|c|}{ Dependent variable: Employment status } \\
\hline Moroccan & $\begin{array}{c}-0.483 * * * \\
(0.022)\end{array}$ & $\begin{array}{c}-0.409 * * * \\
(0.023)\end{array}$ & $\begin{array}{c}-0.384 * * * \\
(0.023)\end{array}$ & $\begin{array}{c}-0.349 * * * \\
(0.023)\end{array}$ & $\begin{array}{c}-0.411 * * * \\
(0.024)\end{array}$ & $\begin{array}{c}-0.824 * * * \\
(0.024)\end{array}$ & $\begin{array}{c}-0.804 * * * \\
(0.025)\end{array}$ & $\begin{array}{c}-0.698 * * * \\
(0.026)\end{array}$ & $\begin{array}{c}-0.689 * * * \\
(0.026)\end{array}$ & $\begin{array}{c}-0.713 * * * \\
(0.026)\end{array}$ \\
\hline Moroccan * Ysm & $\begin{array}{c}0.053 * * * \\
(0.006)\end{array}$ & $\begin{array}{c}0.053^{* * *} \\
(0.006)\end{array}$ & $\begin{array}{c}0.053 * * * \\
(0.006)\end{array}$ & $\begin{array}{c}0.041^{* * *} \\
(0.006)\end{array}$ & $\begin{array}{c}0.056^{* * *} \\
(0.006)\end{array}$ & $\begin{array}{c}0.028 * * * \\
(0.007)\end{array}$ & $\begin{array}{c}0.076^{* * *} \\
(0.008)\end{array}$ & $\begin{array}{c}0.054 * * * \\
(0.008)\end{array}$ & $\begin{array}{c}0.053^{* * *} \\
(0.008)\end{array}$ & $\begin{array}{c}0.059 * * * \\
(0.008)\end{array}$ \\
\hline Moroccan * Ysm2 & $\begin{array}{c}-0.005^{* * *} \\
(0.000)\end{array}$ & $\begin{array}{c}-0.004 * * * \\
(0.000)\end{array}$ & $\begin{array}{c}-0.004 * * * \\
(0.000)\end{array}$ & $\begin{array}{c}-0.003 * * * \\
(0.000)\end{array}$ & $\begin{array}{c}-0.004 * * * \\
(0.000)\end{array}$ & $\begin{array}{c}0.002 * * * \\
(0.001)\end{array}$ & $\begin{array}{l}-0.001 * \\
(0.001)\end{array}$ & $\begin{array}{c}0.001 \\
(0.001)\end{array}$ & $\begin{array}{c}0.001 \\
(0.001)\end{array}$ & $\begin{array}{c}0.000 \\
(0.001)\end{array}$ \\
\hline Ysm & $\begin{array}{c}-0.068^{* * *} \\
(0.006)\end{array}$ & $\begin{array}{c}-0.051 * * * \\
(0.006)\end{array}$ & $\begin{array}{c}-0.038^{* * *} \\
(0.006)\end{array}$ & $\begin{array}{c}-0.028 * * * \\
(0.006)\end{array}$ & $\begin{array}{c}-0.046^{* * *} \\
(0.006)\end{array}$ & $\begin{array}{c}-0.047 * * * \\
(0.008)\end{array}$ & $\begin{array}{c}-0.104^{* * *} \\
(0.008)\end{array}$ & $\begin{array}{c}-0.078 * * * \\
(0.008)\end{array}$ & $\begin{array}{c}-0.078 * * * \\
(0.008)\end{array}$ & $\begin{array}{c}-0.083 * * * \\
(0.008)\end{array}$ \\
\hline Ysm 2 & $\begin{array}{c}0.005^{* * *} * \\
(0.000)\end{array}$ & $\begin{array}{c}0.004 * * * \\
(0.000)\end{array}$ & $\begin{array}{c}0.003 * * * \\
(0.000)\end{array}$ & $\begin{array}{c}0.003 * * * \\
(0.000)\end{array}$ & $\begin{array}{c}0.003 * * * \\
(0.000)\end{array}$ & $\begin{array}{c}-0.002 * * * \\
(0.001)\end{array}$ & $\begin{array}{c}0.001 * \\
(0.001)\end{array}$ & $\begin{array}{l}-0.001 \\
(0.001)\end{array}$ & $\begin{array}{l}-0.001 \\
(0.001)\end{array}$ & $\begin{array}{l}-0.000 \\
(0.001)\end{array}$ \\
\hline & ighted sample siz & & & 1419 & & & & 1073 & & \\
\hline
\end{tabular}

Note: All specifications include region dummies. $* * * \mathrm{p}<0.01, * * \mathrm{p}<0.05, * \mathrm{p}<0.1$ 
Figure 1. Predicted Probabilities from Bivariate Probit Model for a Spanish Fluent Low Skilled Worker Who Worked at Origin
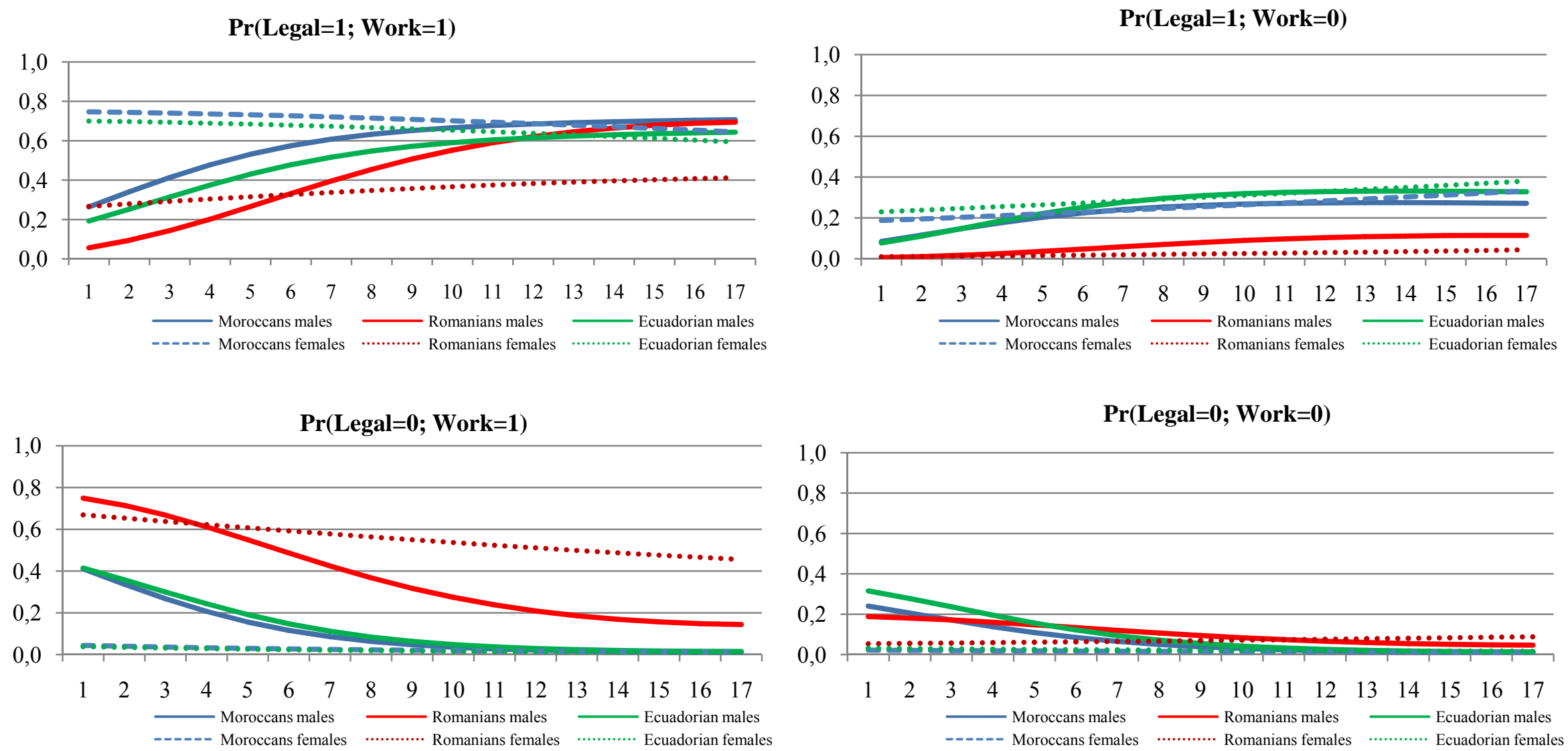
Table 4.A Log Wage Estimation. Moroccans versus Ecuadoreans 19 to 55 Years Old in Spain

\begin{tabular}{|c|c|c|c|c|c|c|c|c|}
\hline & \multicolumn{4}{|c|}{ Men } & \multicolumn{4}{|c|}{ Women } \\
\hline & \multicolumn{2}{|c|}{ OLS } & \multicolumn{2}{|c|}{ Heckman corrected } & \multicolumn{2}{|c|}{ OLS } & \multicolumn{2}{|c|}{ Heckman corrected } \\
\hline & $\begin{array}{l}\text { No other } \\
\text { covariates }\end{array}$ & All controls & $\begin{array}{l}\text { No other } \\
\text { covariates }\end{array}$ & All controls & $\begin{array}{c}\text { No other } \\
\text { covariates }\end{array}$ & All controls & $\begin{array}{l}\text { No other } \\
\text { covariates }\end{array}$ & All controls \\
\hline Moroccan & $\begin{array}{c}-0.177 * * * \\
(0.013)\end{array}$ & $\begin{array}{c}-0.121 * * * \\
(0.012)\end{array}$ & $\begin{array}{l}0.628 * \\
(0.350)\end{array}$ & $\begin{array}{c}0.725 * * \\
(0.342)\end{array}$ & $\begin{array}{c}0.043 * * * \\
(0.014)\end{array}$ & $\begin{array}{c}0.029 * * \\
(0.014)\end{array}$ & $\begin{array}{c}0.481 \\
(0.327)\end{array}$ & $\begin{array}{c}0.369 \\
(0.324)\end{array}$ \\
\hline Moroccan * ysm & $\begin{array}{c}-0.040 * * * \\
(0.003)\end{array}$ & $\begin{array}{c}-0.011 * * * \\
(0.003)\end{array}$ & $\begin{array}{c}0.120 \\
(0.079)\end{array}$ & $\begin{array}{l}0.151 * \\
(0.078)\end{array}$ & $\begin{array}{c}0.001 \\
(0.003)\end{array}$ & $\begin{array}{c}0.013 * * * \\
(0.003)\end{array}$ & $\begin{array}{c}0.141^{* *} \\
(0.066)\end{array}$ & $\begin{array}{l}0.114^{*} \\
(0.066)\end{array}$ \\
\hline Moroccan * ysm_sq & $\begin{array}{c}0.002 * * * \\
(0.000)\end{array}$ & $\begin{array}{c}0.001 * * * \\
(0.000)\end{array}$ & $\begin{array}{l}-0.005 \\
(0.004)\end{array}$ & $\begin{array}{l}-0.007 \\
(0.004)\end{array}$ & $\begin{array}{c}0.001 * * * \\
(0.000)\end{array}$ & $\begin{array}{c}0.001 * * * \\
(0.000)\end{array}$ & $\begin{array}{l}-0.006 \\
(0.003)\end{array}$ & $\begin{array}{l}-0.005 \\
(0.003)\end{array}$ \\
\hline Ysm & $\begin{array}{c}0.045 * * * \\
(0.003)\end{array}$ & $\begin{array}{c}0.023 * * * \\
(0.003)\end{array}$ & $\begin{array}{l}-0.116 \\
(0.078)\end{array}$ & $\begin{array}{l}-0.144 * \\
(0.076)\end{array}$ & $\begin{array}{c}0.003 \\
(0.003)\end{array}$ & $\begin{array}{l}-0.002 \\
(0.003)\end{array}$ & $\begin{array}{l}-0.111 * \\
(0.067)\end{array}$ & $\begin{array}{l}-0.087 \\
(0.066)\end{array}$ \\
\hline Ysm_sq & $\begin{array}{c}-0.002 * * * \\
(0.000)\end{array}$ & $\begin{array}{c}-0.001 * * * \\
(0.000)\end{array}$ & $\begin{array}{c}0.005 \\
(0.004)\end{array}$ & $\begin{array}{l}0.007 * \\
(0.004)\end{array}$ & $\begin{array}{c}-0.001 * * * \\
(0.000)\end{array}$ & $\begin{array}{c}-0.001^{* * *} \\
(0.000)\end{array}$ & $\begin{array}{c}0.005 \\
(0.003)\end{array}$ & $\begin{array}{c}0.004 \\
(0.003)\end{array}$ \\
\hline $\begin{array}{l}\text { Unweighted sample } \\
\text { size }\end{array}$ & \multicolumn{4}{|c|}{504} & \multicolumn{4}{|c|}{472} \\
\hline Goodness of fit ${ }^{1}$ & 0.094 & 0.195 & 58.16 & 93.62 & 0.054 & 0.118 & 30.90 & 56.87 \\
\hline
\end{tabular}

Note: 1 Adjusted R squared in OLS and Chi Square in Heckman corrected specification.

All specifications include region dummies. ${ }^{* * *} \mathrm{p}<0.01,{ }^{* *} \mathrm{p}<0.05,{ }^{*} \mathrm{p}<0.1$ 
Table 4.B Log Wage Estimation. Moroccans versus Romanians 19 to 55 Years Old in Spain

\begin{tabular}{|c|c|c|c|c|c|c|c|c|}
\hline & \multicolumn{4}{|c|}{ Men } & \multicolumn{4}{|c|}{ Women } \\
\hline & \multicolumn{2}{|c|}{ OLS } & \multicolumn{2}{|c|}{ Heckman corrected } & \multicolumn{2}{|c|}{ OLS } & \multicolumn{2}{|c|}{ Heckman corrected } \\
\hline & $\begin{array}{c}\text { No other } \\
\text { covariates }\end{array}$ & All controls & $\begin{array}{c}\text { No other } \\
\text { covariates }\end{array}$ & All controls & $\begin{array}{c}\text { No other } \\
\text { covariates }\end{array}$ & All controls & $\begin{array}{c}\text { No other } \\
\text { covariates }\end{array}$ & All controls \\
\hline Moroccan & $\begin{array}{c}0.065^{* * *} \\
(0.009)\end{array}$ & $\begin{array}{c}0.043 * * * \\
(0.008)\end{array}$ & $\begin{array}{c}0.158 \\
(0.217)\end{array}$ & $\begin{array}{c}0.070 \\
(0.207)\end{array}$ & $\begin{array}{c}0.325 * * * \\
(0.013)\end{array}$ & $\begin{array}{c}0.412 * * * \\
(0.012)\end{array}$ & $\begin{array}{c}0.265 \\
(0.252)\end{array}$ & $\begin{array}{l}\mathbf{0 . 5 3 1 * *} \\
(0.244)\end{array}$ \\
\hline Moroccan * ysm & $\begin{array}{c}0.013 * * * \\
(0.002)\end{array}$ & $\begin{array}{c}0.028^{* * *} \\
(0.002)\end{array}$ & $\begin{array}{l}-0.015 \\
(0.045)\end{array}$ & $\begin{array}{l}-0.005 \\
(0.043)\end{array}$ & $\begin{array}{c}0.098^{* * *} \\
(0.004)\end{array}$ & $\begin{array}{c}0.093 * * * \\
(0.004)\end{array}$ & $\begin{array}{c}0.076 \\
(0.066)\end{array}$ & $\begin{array}{c}0.137 * * \\
(0.062)\end{array}$ \\
\hline Moroccan * ysm_sq & $\begin{array}{c}0.000 \\
(0.000)\end{array}$ & $\begin{array}{c}-0.001 * * * \\
(0.000)\end{array}$ & $\begin{array}{c}0.003 \\
(0.002)\end{array}$ & $\begin{array}{c}0.001 \\
(0.002)\end{array}$ & $\begin{array}{c}-0.003 * * * \\
(0.000)\end{array}$ & $\begin{array}{c}-0.002^{* * *} \\
(0.000)\end{array}$ & $\begin{array}{l}-0.001 \\
(0.005)\end{array}$ & $\begin{array}{l}-0.005 \\
(0.004)\end{array}$ \\
\hline Ysm & $\begin{array}{c}-0.006^{* * *} \\
(0.002)\end{array}$ & $\begin{array}{c}-0.009 * * * \\
(0.002)\end{array}$ & $\begin{array}{c}0.026 \\
(0.046)\end{array}$ & $\begin{array}{c}0.029 \\
(0.044)\end{array}$ & $\begin{array}{c}-0.076^{* * *} \\
(0.004)\end{array}$ & $\begin{array}{c}-0.067^{* * *} \\
(0.004)\end{array}$ & $\begin{array}{l}-0.063 \\
(0.068)\end{array}$ & $\begin{array}{l}-0.108^{*} \\
(0.064)\end{array}$ \\
\hline Ysm_sq & $\begin{array}{c}0.000 \\
(0.000)\end{array}$ & $\begin{array}{c}0.001 * * * \\
(0.000)\end{array}$ & $\begin{array}{l}-0.003 \\
(0.002)\end{array}$ & $\begin{array}{l}-0.001 \\
(0.002)\end{array}$ & $\begin{array}{c}0.003 * * * \\
(0.000) \\
\end{array}$ & $\begin{array}{c}0.002 * * * \\
(0.000) \\
\end{array}$ & $\begin{array}{c}0.001 \\
(0.005)\end{array}$ & $\begin{array}{c}0.004 \\
(0.004) \\
\end{array}$ \\
\hline $\begin{array}{l}\text { Unweighted sample } \\
\text { size }\end{array}$ & \multicolumn{4}{|c|}{471} & \multicolumn{4}{|c|}{444} \\
\hline Goodness of fit ${ }^{1}$ & 0.101 & 0.229 & 67.83 & 133.0 & 0.081 & 0.190 & & \\
\hline
\end{tabular}

Note: 1 Adjusted R squared in OLS and Chi Square in Heckman corrected specification.

All specifications include region dummies. ${ }^{* * *} \mathrm{p}<0.01, * * \mathrm{p}<0.05,{ }^{*} \mathrm{p}<0.1$ 